UDK 78:81’373.46

Pregledni rad

Rukopis primljen 13. VII. 2018.

Prihvaćen za tisak 14. XI. 2018.

Smiljana Narančić Kovač

Faculty of Teacher Education

University of Zagreb

narancic-kovac@ufzg.hr

Iva Kovač

ikovaciva@gmail.com

\title{
NARRATIVE AS A TERM IN NARRATOLOGY AND MUSIC THEORY
}

The paper compares the term narrative as it is used by narratologists, and as it is used by music scholars, to establish whether these two disciplines use the term in the same way, or as two homonyms. Narratological studies in medium-specific models of narratives apply the term to different kinds of discourses, i.e. different media. Music theoreticians and musicologists consider its application in music scholarship with a theory of the musical narrative in view. This analysis shows that in the general theory of the narrative the concept includes both story and discourse, based on the referentiality of the discourse, which necessarily evokes a storyworld. Narratologists generally find music to be incapable of producing a narrative in this sense. Musicologists and theoreticians of music generally acknowledge the limitations of the referentiality of musical discourse, yet they often discover specific, usually abstract, narrative meanings there. Therefore, despite common starting points and principles, the two disciplines use the term narrative to denote two different concepts, which results in two homonymous terms.

\section{Introduction}

The aim of this paper is to compare the term narrative as it is used by contemporary narratologists, and the term narrative as it is used by contemporary theoreticians of music and musicologists in order to establish if it refers to the same or to different concepts.

According to Maria Teresa Cabré, terms are "specialized words occurring in natural language which belong to specific domains of usage" (1999: 32), and terminology "differentiates special languages from the general language and 
also the various special languages from one another" (1999: 45). Ultimately, every term belongs to a specific conceptual system, and while different meanings of the same word in general language imply polysemy, terms are considered monoreferential, so that their different manifestations in different fields of study, which are dependent on the different concepts they refer to, result in homonymy (1999: 108). This means that a term has a strictly defined meaning in each discipline. The focus of the present research is how scholars from two realms interpret the meaning of the term narrative, or, in other words, if this term has a consistent meaning or if it is used homonymously in the two disciplines.

\section{Narrative in narratology}

Narrative is the central term of narratology as a semiotic theory. Some of its major representatives include authors such as Roland Barthes, Gérard Genette (1980 [1972], 1988 [1983]) and Seymour Chatman (1978), classical narratologists. These scholars are among the founders of narratology as a discipline and as a method of research in the humanities, and their concept of the narrative is today generally accepted. Barthes largely contributed to the development of the notion of the narrative in some of his papers published mostly in the 1960s and early 1970s, also by understanding the narrative as a phenomenon "distributed amongst different substances - as though any material were fit to receive man's stories" (Barthes 1966/1977: 79). Genette's study Narrative Discourse: An Essay in Method (1980 [1972]) focuses on literature. Building upon earlier structuralist theories, Genette set the foundations for a systematic theory of the narrative in literature, based on language as its medium. He was interested in how language tells stories. In other words, Genette explores the narrative potential of natural language. For him, a literary work is identical with its discourse, and all the meanings are provided by the medium of language.

Chatman (1978) follows Barthes in widening the term to other media; he studies literature and other systems of signification, such as film and comics. He establishes the model of the narrative based on Louis Hjelmslev's model of sign, which embraces the categories of content and expression, both of which include form and substance, so that there are four combinations of these categories: the 
form of content, the substance of content, the form of expression and the substance of expression (Hjelmslev 1980 [1943]: 58). Chatman re-interprets these combinations in his basic model of the narrative (Chatman 1978: 24). In the narrative, the level of content is identical with "story", and the level of expression with "discourse" (Fig. 1). The substance of story is described as "[r]epresentations of objects \& actions in real \& imagined worlds", the form of story through its components, "events, existents, and their connections", the substance of discourse as "[m]edia insofar as they can communicate stories", and the form of discourse as "consisting of elements shared by narratives in any medium whatsoever" (ibid.). Starting from this division, Chatman develops a more elaborate model of the narrative which includes the most important and defining elements of the story and the discourse (Fig. 1).

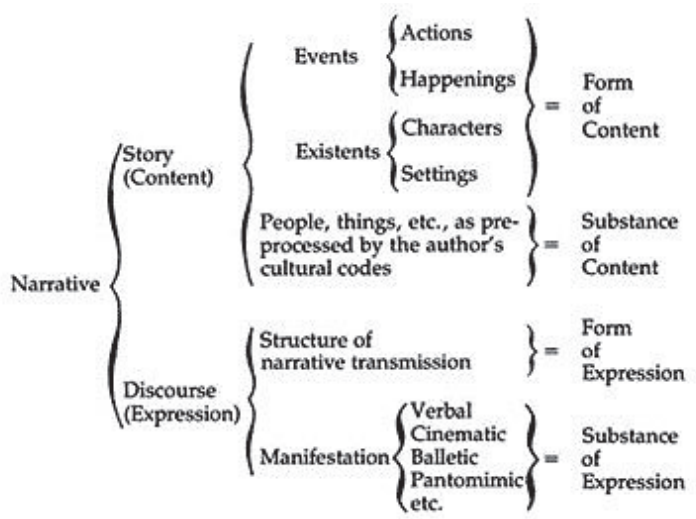

Figure 1. Chatman's extended model of the narrative (1978: 26)

Chatman's model can be visually restructured to expose the common core of all the narratives more clearly, and to emphasise the elements which are interchangeable in specific narratives, dependent on the medium of communication on the one hand, and on the selection of the elements of the story on the other hand (Fig. 2). This representation emphasises that the narratological view of the narrative presupposes the specific narrative form for any particular content and any particular medium as a condition of establishing a narrative. Thus, narratives may exist in different media of expression, and they can tell the same story, or different stories, but both components, the story and the discourse, are necessary to produce a narrative. 


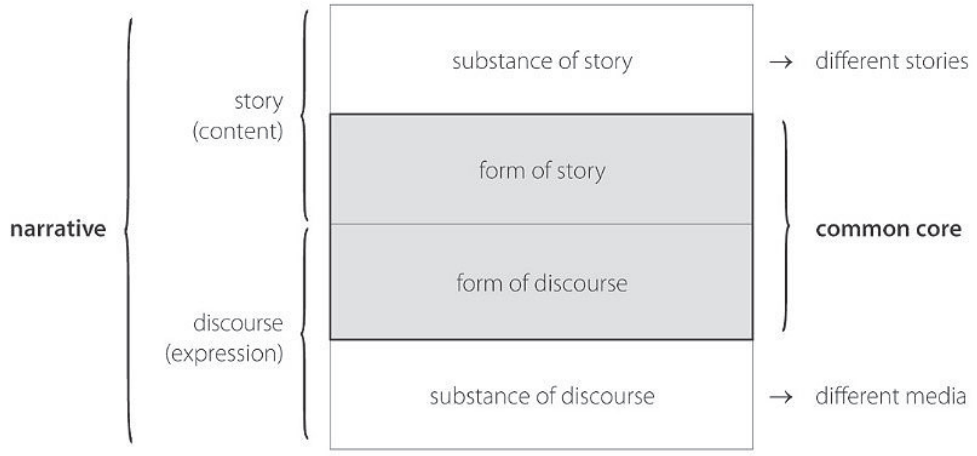

Figure 2. General model of the narrative developed from Chatman's model (Narančić Kovač 2018: 410)

In consequence, and in its further development, the theory of the narrative has become a study of different "languages of storytelling" (Ryan 2004), and new approaches have appeared. For instance, transmedial narratology (Herman 2004) and media-conscious narratology (Ryan and Thon 2014) focus on the kinds of narrative which appear in specific media, acknowledging the common features of the narrative. As Marie-Laure Ryan and Jan-Noël Thon put it, the central structure all narratives share is associated "not with a particular narrative but more generally with the abstract type of content constitutive of 'narrativity,' a content that we can define as that which all stories share. Here, again, the concept of storyworld plays a prominent role, for it captures the kind of mental representation that a text must evoke in order to qualify as narrative" (2014: 3).

The ideas of "narrativity" and "storyworld" slightly extend the idea of the previously mentioned content (story) aspect of the narrative "common core" (Fig. 2). Ryan lists the following elements of the storyworld: existents (characters and objects), the setting, physical laws, social rules and values, events (in a time-span frame), and mental events (2014: 34-36). Besides, a storyworld often migrates from medium to medium (Ryan and Thon 2014: 19), which means that the same story(world) may appear in a novel, a play, a film, a picturebook, a comic, etc. As a result, more recent developments of the theory of the narrative have brought nothing new in terms of the necessity of a story (developed primarily through characters, events, and settings) for the creation of a narrative. 


\section{Narrative in music theory and musicology}

Since music is a medium, and a kind of discourse, it is not surprising that the term narrative has also appeared in musicology and in the theory of music. It is usually used to describe music in its temporality. Music scholars consider the possibility of narrativity in music and attempt to establish a theory of musical narrative.

Starting from the above-mentioned definition of term as a word which has different meanings in different disciplines, we expect to find the concept of narrative in music scholarship to be different from the concept of narrative in narratology. To test this proposition, we analysed the concepts of narrative which appear in studies by several theoreticians of music and musicologists, presented below in chronological order. The studies in focus were published in a period spanning 25 years, from 1988 until 2013: Patrick McCreless (1988), Jean-Jacques Nattiez (1990), Eero Tarasti (2002), John Roeder (2006), Byron Almén (2008), Kofi Agawu (2009), and Michael L. Klein (2013). The term and the concept of narrative in music are directly connected with the development of the theory of the musical narrative, although a complete overview of this field remains beyond the scope of our paper.

McCreless (1988: 2) points out that a productive contact needs to exist between relevant disciplines in order to be able to attempt to answer questions such as "What does music narrate, if anything?" He starts from the theory of five codes as elements of narratives, introduced by Roland Barthes in the essay $S / Z$ (Barthes 1974 [1970]), ${ }^{1}$ and looks at them from a musical perspective.

Barthes distinguishes between "writerly" and "readerly" texts. Writerly texts make it possible for the reader to be "no longer a consumer, but a producer of the text" (1974 [1970]: 4). Such a text embraces different codes as "voices out of which the text is woven" (1974 [1970]: 21), while the codes turn it into an area of "an iridescent exchange carried on by multiple voices" (1974 [1970]: 41). Conversely, when encountering a readerly text, the reader is "plunged into a kind of idleness [...], he is left with no more than the poor freedom either to accept or reject the text" (ibid.). Barthes explains the notion of readerly texts in reference

\footnotetext{
These codes include: the hermeneutic or enigma code, the proairetic or action code, the semantic code, the symbolic code and the cultural or reference code. The first two are sequential or narrative codes, which build tension and interest in readers, the third and the fourth provide additional meanings and the last one refers to general truths and extratextual knowledge (Barthes 1974 [1970]).
} 
to music: "The readerly text is a tonal text [...] and its tonal unity is basically dependent on two sequential codes: the revelation of truth and the coordination of the actions represented: there is the same constraint in the gradual order of melody and in the equally gradual order of the narrative sequence" (1974 [1970]: 30).

McCreless (1988) looks for possible manifestations of each of the five codes in music, but after a brief consideration of the symbolic, referential, proairetic and semantic codes, he concentrates mainly on the hermeneutic or enigma code, the code of suspense, which he considers to be the most suitable for music, in particular in "those works $[. .$.$] that employ the technique of expanding a chromatic$ detail into a structural issue at deeper levels" (1988: 16). To exemplify this, McCreless takes a look at the trajectory of the chromatic $\mathrm{F}$ in the first movement of Beethoven's "Ghost Trio" in terms of the hermeneutic code, clarifying that "the exposition of the $1^{\text {st }}$ movement seems to make a hermeneutic issue of how the $\mathrm{F}$ resolves" (McCreless 1988: 22). Since this movement is written in D-Major, the listener expects to hear an F\# in bar 5, so the chromatic F is heard as marked and demands a resolution (see Fig. 3). In different stages of the movement, the $\mathrm{F}$ resolves either into an F\#, or into an E. According to McCreless, "the F poses the central hermeneutic enigma, the crucial function of this work" (1988: 25). He does not explicitly reflect on the notion of narrative, and focuses on how rather than on what music narrates. However, he modifies the narratological concept of the narrative as he applies the codes in the analysis of the discourse, rather than of narrative meanings, which would be dependent on the elements of story.

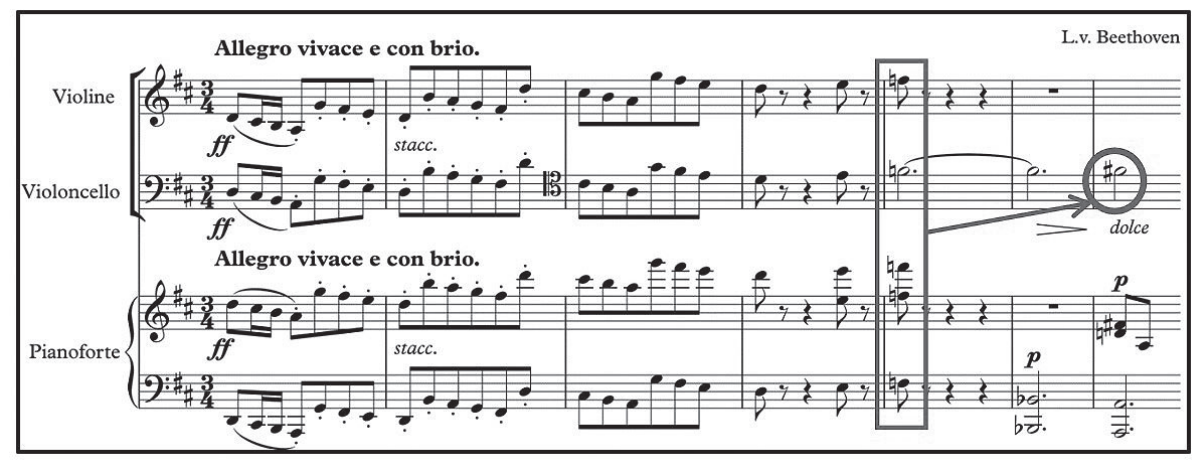

Figure 3. The enigma of the chromatic $\mathrm{F}$ in the opening bars of Ludwig van Beethoven's Piano Trio in D Major, op. 70, No. 1 (Ghost), $1^{\text {st }}$ movement, which is explained by McCreless (1988). 
Jean-Jacques Nattiez (1990) asks if one can speak of narrativity in music and offers an answer: for him, music is not a narrative. He explains that there is "a clear ontological difference between literary narrative and musical "narrative"" (Nattiez 1990: 242), and stresses the fictionality of literary narratives, saying that they, unlike music, lie (Nattiez 1990: 244). For Nattiez, narrativity in music seems to be plausible because of the temporality of music, as well as because of its syntactical dimension (ibid.). However, music only resembles the narrative at the level of discourse; there is no story in it: "I recognize returns, expectations and resolutions, but of what, I do not know" (Nattiez 1990: 245). He supports his view with an account of an experiment in which he played Paul Dukas's symphonic poem "L'apprenti sorcier" [The Sorcerer's Apprentice] to 300 schoolchildren, without giving them the title, and then asked them to write down the story which they could hear in the musical piece. Naturally, the resulting stories were very different, although they displayed a certain similarity in their formal construction, that is, at the level of discourse. Nattiez concludes that music is not a narrative in itself, but that a narrative can be found in an analysis, or that a plot may be "constructed by the listeners" (1990: 249). His notion of narrative coincides with that of narratology. In his view, when it is applied to music, the story can be provided only by the recipients, and then a narrative is created.

Eero Tarasti arrives at a different conclusion, i.e. that a musical narrative exists. In his study Signs of Music, he focuses on music "as sign and communication" (Tarasti 2002: v), which shows that he starts from the same foundations as narratologists. He claims that musical signifiers are "supposed to have another side, that of signifieds" (2002: 59), in other words that music communicates meanings by means of musical signs, although "musical meanings are not lexicographic, but always depend on the context in which they appear" (2002: 8). Tarasti sees melodies as "virtual 'actors" and as "protagonists of musical discourse" (2002: 30); he speaks of "theme-actors" (2002: 74), and, in another spot, he ascribes the role of actors to "gestural themes" or "actorial gestures" that listeners may identify with (2002: 39). He represents tonality as "the deep structure of the immanent narrativity of music" (2002: 31). His interpretation of Beethoven's sonata "Les adieux" uses terminology typical of studies in narrative theory, for example: "a narrator arranges the events into a plot which he assumes that his audience will 'decode' correctly" (Tarasti 2002: 74). 
For Tarasti, musical narrativity is based on the process of unfolding in time, which makes it possible for the listeners to experience musical significations. Therefore, music is "the supreme temporal art" (2002: 23). Tarasti is confident that "music signifies" (2002: 65), and he arrives at the conclusion that music, being a temporal art, "is thus one of the best means of narrativizing transcendental ideas" (2002: 112). He builds upon major semioticians, but re-interprets the concept of the narrative, especially the nature of the elements of the story and their meanings.

John Roeder (2006) analyses Elliott Carter's "Enchanted Preludes" for flute and cello as a narrative, observing the two instruments as characters. Roeder describes the rhythmical and pitch interactions of the two instruments with words which one usually uses to describe people who communicate: the instruments "respond positively" or "negatively to each other", they "cooperate", "react", "acknowledge each other's pitch territories", "compete"; there is a "dialog", a "conflict", they "deliberately" choose their pitches (2006: 385-386, 412). Although he uses the term narrative to denote a purely musical description of the piece, Roeder sees it as a possible depiction of a "close marital relationship" or even as an "affirmation of the democratic ideals of the composer's society" (2006: 412).

This societal aspect, slightly touched on by Roeder, becomes central in the work of Byron Almén (2008). In his view, deriving a musical narrative from the literary narrative in what he calls a "descendant model" makes the meaning of musical narrative "parasitic", because it is then generated only in reference to its imaginary verbal "equivalent" (Almén 2008: 12). In this view, music is necessarily inferior to literature, as well as "insufficiently and ineffectively" narrative: it isn't strictly defined semantically, and neither has it a recognisable narrator nor specific characters (ibid.). If we conceive of a musical narrative in this way, the following question arises: "Wouldn't writing a story be much more effective?" (ibid.).

Instead of settling for the inevitable answer to this rhetorical question, Almén opts for a "sibling model" of the theory of the musical narrative (ibid.), which follows recent developments in narratology (transmedial narratology and mediumconscious narratology, see above). Almén sees the lack of semantic aspects in 
music as a positive characteristic, because "music can display narrative activity without being limited to specific characters and settings" (Almén 2008: 13). In this, he is close to Tarasti, who believes that music tells stories about transcendental, abstract ideas.

In his book, Almén lists core properties of any narrative. He explains that a narrative displays "a particular set of hierarchical relations subjected to crisis," and then tracks "the consequences of this crisis" (2008: 22). Those hierarchical relationships, and, through them, also the narrative itself, become psychologically, culturally and socially significant through the recipient's (reader's or listener's) interpretation. These observations lead Almén to a definition of narrative as transvaluation (2008: 40), a term coined by James Jakób Liszka (1989). Because any narrative is ultimately dependent on the observer's perspective, and especially because music has no semantic specificity, Almén believes that musical discourse can offer multiple meanings and "articulat[e] these [narrative] patterns with wider applicability and greater immediacy" (2008: 27).

Kofi Agawu is another scholar who sees music as discourse. He believes that a piece of music has the form of an ordered and related "sequence of events" (2008: 7), described as a "narrative thread" (2008: 11). When performed, it makes "a meaningful impression on the listener", who needs to be well acquainted with the musical code, and is at the same time influenced by cultural and historical factors (2008: 4-7). Agawu emphasises that musical meaning is "contingent", and points towards the similarity of analysis and performance (ibid.). Agawu compares music and language, and finds, for example, that temporality is their common feature (2008: 24). However, he thinks that music is inferior to language, and consequently to literature, too, in its "discursive communicative capacity" (2008: 22). Furthermore, music cannot communicate referential meanings: words have a more or less fixed lexical meaning, while musical units, whether tones, phrases or melodies, do not (2008: 25).

Agawu's approach to the term narrative is somewhat paradoxical: on the one hand, he believes the concept of narrative is relevant for music due to its temporality, and to "the human need to understand succession coherently" (2008: 102). On the other hand, he claims that music also displays a tendency to "refuse narration" (ibid.), mostly because of numerous repetitions, which belong to its intrinsic aspects (Agawu 2008: 103f). 
In his introductory chapter to Music and Narrative after 1900, Michael L. Klein (2013) gives a short overview of previous attempts at defining the musical narrative and states that they tend to use narrative metaphors to analyse music (11-15). Speaking of music after 1900, Klein warns that hovering on such metaphors collapses story into discourse (2013: 18). This warning could, however, equally be applied to tonal music. Klein claims that there is no way that leads from the discourse to the story; as he puts it, "[o]ne simply jumps into the story" (ibid.).

In Klein's opinion, story needs to be considered if we use narrative theory to discuss music. If not, there is a danger of seeing music as a mere empty form (2008: 24), because a narrative without a story is no narrative, or, in his own words, "a discourse without a story is a sad excuse for a narrative" (2013: 23). He emphasises the connection between narrative and interpretation and finds similarities between stories and performances of music (2013: 21, 23). Thus, in his opinion, we do not expect musical narratives to tell the whole story, because performances do not either, but we may nevertheless be encouraged to look for and to find stories in music.

\section{Final remarks}

We can agree with Klein (2013) that music scholars tend to focus on discourse and generally admit the lack of (denotative) referentiality in music. In the analysed approaches, they often interpret elements of discourse, such as melodies or themes, as elements of story, and ascribe them the roles of characters or meanings of events in musical narratives. However, these narrative meanings remain abstract or metaphorical, so music can indeed be considered as "signif[ying] both too much and too little" (Klein 2013: 19).

As shown above, in the general theory of the narrative, this central concept embraces both the story and the discourse, and is founded on the referentiality of the discourse, which necessarily evokes a storyworld. Although narratologists do not deny that music can participate in combined-media narratives, such as films, musicals, operas, songs, etc., (cf. Barthes 1970/1977, Hansen 2010), they think that music as a medium cannot autonomously produce a narrative. Music is not without sense, but its meanings are abstract: those meanings are derived from the medium itself and, in narratological terms, they are not stories. 
When music scholars adopt the term narrative, they, with some exceptions (Nattiez, for instance), refer to somewhat different meanings from those implied by narratologists. Even when they acknowledge the necessity of the presence of the elements of story in the narrative, they do not expect them to be concrete or determined by a (musical) text. They either leave the construction of the narrative content (the story) to the recipients, or replace its elements with abstract meanings. Music theorists and musicologists usually consult narratological research, but they often modify its findings to fit music, or their own views on music. Therefore, despite common starting points and principles, the two disciplines use the word narrative to denote two different concepts, and it thus represents two homonymous terms.

\section{References:}

Agawu, Kofi. 2008. Music as Discourse: Semiotic Adventures in Romantic Music. Oxford University Press. New York.

Almén, Byron. 2008. A Theory of Musical Narrative. Indiana University Press. Bloomington.

Barthes, Roland. 1970/1977. Musica Practica. Transl. by Stephen Heath. Image-Music-Text. Hill and Wang. New York. 149-154.

Barthes, Roland. 1966/1977. Introduction to the Structural Analysis of Narratives. Transl. by Stephen Heath. Image-Music-Text. Hill and Wang. New York. 79-124.

Barthes, Roland. 1974 [1970]. S/Z. Transl. by Richard Miller. Hill and Wang. New York. CABré, Maria Teresa. 1999. Terminology: Theory, Methods, and Applications. Transl. by Janet Ann DeCesaris. John Benjamins Publishing. Amsterdam/Philadelphia.

Chatman, Seymour. 1978. Story and Discourse: Narrative Structure in Fiction and Film. Cornell University Press. Ithaca.

GenetTe, Gérard. 1980 [1972]. Narrative Discourse: An Essay in Method. Cornell University Press. Ithaca.

Genette, GérARd. 1988 [1983]. Narrative Discourse Revisited. Cornell University Press Ithaca.

Hansen, Per Krogh. 2010. All Talking! All Singing! All Dancing!. Intermediality and Storytelling. Eds. Grishakova, Marina; Marie-Laure Ryan. De Gruyter. Berlin - New York. 147-164.

Herman, David. 2004. Toward a Transmedial Narratology. Narrative Across Media. Ed. Ryan, Marie-Laure. University of Nebraska Press. Lincoln. 47-75. 
Huelmslev, Louis. 1980 [1943]. Prolegomena teoriji jezika. Transl. by Ante Stamać. GZH. Zagreb.

Klein, Michael L. 2013. Musical Story. Music and Narrative Since 1900: Musical Meaning and Interpretation. Eds. Klein, Michael Leslie; Reyland, Nicholas W. Indiana University Press. Bloomington. 3-28.

Liszka, James JAKóB. 1989. The Semiotic of Myth: A Critical Study of the Symbol. Indiana University Press. Bloomington.

McCreless, Patrick. 1988. Roland Barthes' S/Z from a Musical Point of View. In Theory Only 10/7. 1-29.

Narančić Kovač, Smiljana. 2018. Picturebooks and Narratology. Routledge Companion to Picturebooks. Ed. Kümmerling-Meibauer, Bettina. Routledge. London. 409-419.

Nattiez, Jean-Jacques. 1990. Can One Speak of Narrativity in Music? Transl. by Katharine Ellis. Journal of the Royal Musical Association 115/2. 240-257.

Rabinowitz, Peter J. 1981. Fict ional Music: Toward a Theory of List ening. Theories of Reading, Looking and Listening. Ed. Garvin, Barry R. Bucknell University Press. Lewisburg. (Bucknell Review 26/1). 193-208.

Roeder, John. 2006. Autonomy and Dialog in Elliott Carter's Enchanted Preludes. Analytical Studies in World Music. Ed. Tenzer, Michael. Oxford University Press. Oxford, UK - New York. 377-414.

Ryan, Marie-Laure. 2014. Story/Worlds/Media: Tuning the Instruments of a MediaConscious Narratology. Storyworlds Across Media. Eds. Ryan, Marie-Laure; Thon, Jan-Noël. University of Nebraska Press. Lincoln. 25-49.

Ryan, Marie-Laure. Ed. 2004. Narrative Across Media: The Languages of Storytelling. University of Nebraska Press. Lincoln - London.

Ryan, Marie-Laure; Thon, JAn-NoËL. Eds. 2014. Storyworlds Across Media: Towards a Media-Conscious Narratology. University of Nebraska Press. Lincoln.

Ryan, Marie-Laure. 2010. Fiction, Cognition and Non-Verbal Media. Intermediality and Storytelling. Ed. Grishakova, Marina; Ryan, Marie-Laure. De Gruyter. Berlin New York. 8-26.

Tarasti, Eero. 2002. Signs of Music: A Guide to Musical Semiotics. De Gruyter Mouton. Berlin.

Winters, Ben. 2012. Music and Narrative: An Introduction. Music, Sound, and the Moving Image-MSMI 6/1. 3-7. 


\section{Pripovijed kao termin u naratologiji i u glazbenoj teoriji}

\section{Sažetak}

$\mathrm{U}$ radu se uspoređuje termin pripovijed (narrative) kako ga razumiju naratolozi i kako ga razumiju teoretičari glazbe i muzikolozi. Cilj je rada utvrditi javlja li se on u dvjema teorijskim disciplinama na isti način, kao jedinstven termin, ili je riječ o dvama homonimima. Naratološke studije medijski osjetljivih modela pripovijedi primjenjuju taj termin na različite vrste diskursa, tj. nalaze ga u različitim medijskim manifestacijama. Glazbeni teoretičari i muzikolozi razmatraju njegovu primjenu u glazbi te nastoje uspostaviti teoriju glazbene pripovijedi. Usporedba upotrebe termina pokazuje da u općoj naratologiji pojam pripovijedi obuhvaća i priču i diskurs te da se zasniva na referencijalnosti diskursa, koji nužno priziva pričosvijet (storyworld). Naratolozi drže da glazba ne može proizvesti pripovijed u tom smislu. Muzikolozi uglavnom prihvaćaju mišljenje o ograničenoj referencijalnosti glazbenoga diskursa, ali u njemu ipak nalaze specifična, često apstraktna pripovjedna značenja. Stoga, usprkos zajedničkim polazištima i načelima, dvije se discipline terminom pripovijed služe kako bi označile dva različita pojma, što dovodi do pojave homonima.

Keywords: narrative, music theory, storyworld, discourse, terminology

Ključne riječi: pripovijed, glazbena teorija, pričosvijet, diskurs, terminologija 


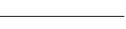

